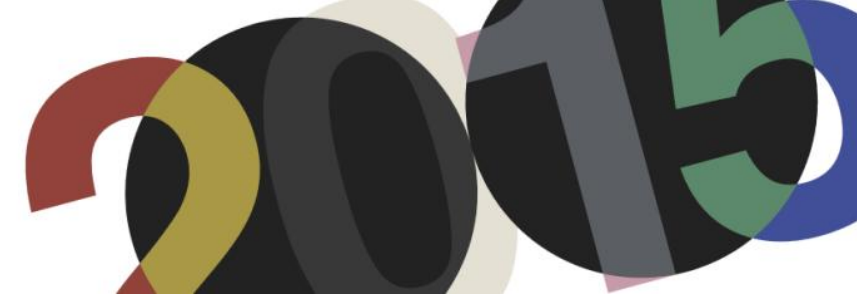

DOI: http://dx.doi.org/10.4995/LC2015.2015.791

\title{
Le Corbusier: architecture, music, mathematics: longing for classicism?
}

\author{
C.G. Gonçalves*, M.J. Soares** \\ * CITAD, Universidade Lusíada de Lisboa / ISMAT \\ ** CITAD, Universidade Lusíada de Lisboa
}

\begin{abstract}
This paper aims to study the role of the relationships between architecture, music and mathematics in Le Corbusier's thought and work and their relevance in his reinterpretation of classical thinking. It seeks to understand to what extent working with this triad - a foundational and, up until the seventeenth century, dogmatic aspect of architecture in general and of its aesthetics in particular - expresses a will not to break with the fundamental and defining aspects of what could be considered as architectural thought rooted in classical tradition: that which is governed by the will to follow the universal order in the work of art; building a microcosmos according to the macrocosmos; linking, in proportion to one another, the universe, man and architecture. The Modulor presents itself as a manifestation of that will, synthesizing these aspects while proposing itself as an instrument for interdisciplinary thought and practice in which the aforementioned aspects of classical thought are present, clearly and pronouncedly. Le Corbusier's thought and work presents itself as a twentieth century memory of an ancient and ever present tradition conscious of its struggle for "humanity".
\end{abstract}

Resumen: Este artículo pretende estudiar el papel de la relación entre arquitectura, música y matemática en el pensamiento y la obra de Le Cobusier y su significado en su reinterpretación del pensamiento clásico. Intenta entender en qué medida con esta triada - aspecto fundacional y hasta el siglo XVII dogmático de la arquitectura, en general, y de su estética, en particular - Le Corbusier expresa su recusa por cortar el vínculo con los aspectos fundamentales y definidores de lo que puede considerarse un pensamiento de tradición clásica en arquitectura: aquel tutelado por la voluntad de seguir el orden universal en la obra de arte - construyendo un microcosmos según un macrocosmos - para así vincular, a través de la proporción, universo, Hombre y arquitectura. El Modulor se presenta como manifestación de esa voluntad, sintetizando estos aspectos y presentándose como un instrumento para un pensamiento y una práctica interdisciplinares en los cuales el pensamiento clásico se encuentra clara y marcadamente presente. El pensamiento de Le Corbusier, través su mirada hacia la relación arquitectura-música-matemática, se presenta, en el siglo $X X$, como una memoria de una antigua y siempre presente tradición, consciente de su busca por "humanidad".

Keywords: Le Corbusier; Architecture, music and mathematics; classical thought; Modulor.

Palabras clave: Le Corbusier; Arquitectura, música y mathematica; pensamiento clásico; Modulor.

\section{Introduction}

One of the most fascinating themes in studying the history of architecture is relating tradition with modernity. One discovers that there is a tradition to being modern and that sometimes these two aspects can, almost unexpectedly, manifest themselves simultaneously within the same person. This seems to be the case with Le Corbusier.

It is well known that twentieth century modernism was a backdrop for passionate debate on tradition. One of modernism's foremost protagonists - Arnold Schoenberg (1874-1951) - very ably defined what was, paradoxically, a lucid position; that from an accepted and beloved, but outdated, tradition one can create a new order that strives to become a new tradition: "I venture to credit myself with having written truly new music 
which, being based on tradition, is destined to become tradition." If the topic were architecture, this could be Le Corbusier's discourse.

Tradition is deeply linked with the idea of the classical or even classicism. This idea of classical refers to a way of thinking - of reading the world and relating it to architecture - and eventually to a method.

It is no coincidence that in Modern Architecture Since 1900 William Curtis begins the chapter "Form and Meaning in the Late Works of Le Corbusier" with this quotation from Henri Focillon: "The principle which gives support to a work of art is not necessarily contemporary with it. It is quite capable of slipping back into the past or forward into the future... The artist inhabits a time which is by no means necessarily the history of his own time." And in The Classical Language of Architecture, John Summerson describes Le Corbusier as "the most inventive mind in the architecture of our time and also, in a curious way, one of the most classical minds"3.

\section{Architecture, music and mathematics}

Founded in Antiquity - with the Pythagorean School, to be precise - the tradition strongly linked with classical thinking in general, and Humanism in particular, that links proportions in architectural to intervals in music through mathematical relations, was also deeply rooted and also further developed during the Middle Ages. In reality, that tradition was only broke in the mid- $17^{\text {th }}$ century. However, despite that chiasm, it does not seem to have totally disappeared from subsequent architectural thought.

In this tradition, along with mathematics, music has always enjoyed a special status, in part precisely because of its correlation to mathematics - both geometry and arithmetic. This aspect fascinated architects and provided them with tools to bring their works into line with the laws of the universe. Whilst it is true that this scenario was seriously challenged in the $17^{\text {th }}$ century, the aura was not gone forever and the spirit within which it was built remained. And, of course, music continued to fascinate architects (as well as many other authors and scholars). It is important to mention that throughout history it is more frequent that architects seek theoretical knowledge or inspiration in music than the opposite. ${ }^{4}$

\subsection{Music and mathematics}

“La musique est évidemment une des joies de la vie.” [Fig.1]

Considering himself a "musician at heart", two ideas related to music, as stated in The Modulor ${ }^{6}$, fascinated Le Corbusier: one was the fact that music, with scarce means, was able to generate infinite solutions that were all different from each other; the other was that music was governed by simple, clear and "economic" rules.

Accordingly, for Le Corbusier music had gone further than architecture and was thus an example to be followed: “... how many of us know that in the visual sphere - in the matter of lengths - our civilizations have not yet

\footnotetext{
${ }^{1}$ Schoenberg, Arnold, Style and Idea, p.174.

${ }^{2}$ Curtis, William, Modern Architecture Since 1900, p. 271.

${ }^{3}$ Summerson, John. The Classical Language of Architecture, p. 111.

${ }^{4}$ For a general study on architecture and music see Gonçalves, Clara Germana, Arquitectura: diálogos com a música: concepção, tradição, criação.

${ }^{5}$ Le Corbusier, Modulor 2, 1955 (Let the User Speak Next: Continuation of "The Modulor" 1948), p.330. In the final paragraph of the book.

${ }^{6}$ Le Corbusier, The Modulor: A Harmonious Measure to the Human Scale Universally Applicable to Architecture and Mechanics.
} 
come to the stage they have reached in music? Nothing that is built, constructed, divided into lengths, widths, volumes, has yet enjoyed the advantage of a measure equivalent to that possessed in music, a working tool in the service of musical thought."7

This constant fascination with music throughout history in general, and the history of architecture in particular, is continued today in the works of authors such as Marcos Novak (b.1957) who argues that "music has reinvented itself in far more profound ways than architecture has dared" ${ }^{\prime \prime}$.

However, for Novak to link architecture and music under the Pythagorean-Platonic tradition is to associate the former with the cadaver of a cosmological musical tradition that has been dead for a long time. He is speaking out against a tradition that still exists. And he refers to one of the most important of Le Corbusier's collaborators, Iannis Xenakis (1922-2001): "Xenakis claims that we are all Pythagoreans. Perhaps this is so, since we are obviously still enamored with numbers. Most of our conceptions about the relationship of architecture and music are remnants of Pythagorean belief. The most prevalent conception is concerned with the static balance of fixed, perfect parts, eternal because desiccated, desiccated because imagined to preexist in an ideal, immaterial world." ${ }^{9}$ In Musique, Architecture, Xenakis had indeed claimed: "We are all Pythagoreans." 10 He also focuses on a note citing Bertrand Russel (1872-1970) in 1924: "Perhaps the oddest thing about modern science is its return to Pythagoricism." "It would seem that the paradox was not exclusive to architecture...

Xenakis' mentor, Le Corbusier, was also fascinated by this tradition. And he considered himself not only a musician but also a "mathematician at heart"12. The following shows how passionately and poetically Le Corbusier spoke of mathematics:

"Mathematics is the majestic structure conceived by man to grant him comprehension of the universe. It holds both the absolute and the infinite, the understandable and the forever elusive. It has walls before which one may pace up and down without result; sometimes there is a door: one opens it-enters - one is in another realm, the realm of the gods, the room which holds the key to the great systems. These doors are the doors of the miracles. Having gone through one, man is no longer the operative force, but rather it is his contact with the universe. In front of him unfolds and spreads out the fabulous fabric of numbers without end. He is in the country of numbers. He may be a modest, and yet have entered just the same. Let him remain, entranced by so much dazzling, all-pervading light." 13

But music came at first. Le Corbusier describes arriving at mathematics through music: "More than these thirty years past, the sap of mathematics has flown through the veins of my work, both as an architect and painter; for music is always present within me."14

\footnotetext{
${ }^{7}$ Le Corbusier, The Modulor, pp.16-17.

${ }^{8}$ Novak, Marcos, "Breaking the Cage", p.69. And he continues: "In this century alone, we have witnessed a series of emancipations: in Arnold Schönberg, the emancipation of dissonance; in Edgard Varèse, the emancipation of noise; in Iannis Xenakis, the emancipation of stochastic form; in John Cage, the emancipation of nonintention." Novak, Marcos, "Breaking the Cage", p.70.

${ }^{9}$ Novak, Marcos, "Breaking the Cage", pp. 69-70.

${ }^{10}$ Xenakis, Iannis. Musique, Architecture, p.73.

${ }^{11}$ As cited in Xenakis, Iannis, Musique, Architecture, p.73. Originally published in The Nation, 27-9-1924.

${ }^{12}$ Le Corbusier, “The Final Year: a Transcription and Translation of Le Corbusier's Last Recorded Interview”, p. 119.

${ }^{13}$ Le Corbusier, The Modulor, p.71.

${ }^{14}$ Le Corbusier, The Modulor, p.129.
} 
And he cites Jean-Philippe Rameau (1683-1764), for whom music was the foundational discipline:

"... 'Music is not a part of mathematics; on the contrary, it is the sciences which are a part of music, for they are founded on proportion, and resonance of the body of sound engenders all proportion." 15

And in emphasising that it is music - particularly harmony - that dominates, he goes on to develop Rameau's idea:

"This last audacious statement is by Rameau, and it throws light on our investigation: music rules all things, it dominates; or, more precisely, harmony does that. Harmony, reigning over all things, regulating all the things of our lives, is the spontaneous, indefatigable and tenacious quest of man animated by a single force: the sense of the divine, and pursuing one aim: to make a paradise on earth." 16

But whilst it was music that led him to mathematics, it would also appear to be true that his fascination for music was due, at least in part, to the traditional and close links between music and mathematics. The foreword to The Modulor $^{17}$ already makes reference to Pythagoras and the beginnings of Greek musical systematisation based on mathematics. This is revealed in the quotations Le Corbusier uses of authors who argue that mathematics and music are inseparable:

"... 'Music is a secret mathematical exercise, and he who engages in it is unaware that he is manipulating numbers. ${ }^{18}$ (Leibnitz.)

... 'The man practising on the keyboard is unaware that he is handling logarithms.' (Henri Martin.)"'19

One must also consider that in the 1950 s mathematics was a study discipline of choice. And at the time many studies on geometry applied to nature and art were carried out. See, for example, the vast body of work produced by Matila Ghyka (1881-1965) ${ }^{20}$ who was a friend to Le Corbusier. This prominence of mathematics was also manifested in events such as the international conference on De Divina Proportione organised by the Milan Triennale in 1951, in which Le Corbusier took part. According to Rudolf Wittkower ${ }^{21}$, this conference had an impact on the Modulor 2 (although the impact on the younger generation was not quite so substantial).

This was followed, by way of example, by a debate 22 at RIBA on 18 June 1957 on the notion "that systems of proportion make good design more easier and bad design more difficult". Forty eight members of the audience voted for the motion while sixty voted against. Bruno Zevi (1918-2000) welcomed this defeat declaring that "no one really believes any longer in the proportional system" ${ }^{\prime 23}$. What about Le Corbusier? Forty eight against sixty

\footnotetext{
${ }^{15}$ Le Corbusier, The Modulor, p.74.

${ }^{16}$ Le Corbusier, The Modulor, p.74.

${ }^{17}$ Le Corbusier, The Modulor, p.16.

${ }^{18}$ This quotation can be found, not surprisingly, in the article by Matila Ghyka, "Frozen Music", p.187.

${ }^{19}$ Le Corbusier, The Modulor, p.74.

${ }^{20}$ One should mention in particular the works Esthétique des proportions dans la nature et dans les arts (1927), Le nombre d'or: rites et rythmes pythagoriciens dans le développement de la civilisation occidentale (1931) and The Geometry of Art and Life (1946) which would seem to have been decisive both in the creation and written formulation of the The Modulor. According to Jean-Louis Cohen, Le Corbusier had copies of the first two books. "Le Corbusier's Modulor and the Debate on Proportion in France", p.3.

${ }^{21}$ Wittkower, Rudolf, "The Changing Concept of Proportion", p.210.

${ }^{22}$ See Pevsner, Sir Nikolaus, "Report of a Debate on the Motion 'that Systems of Proportion make good design easier and bad design more difficult"'.

${ }^{23}$ As cited in Wittkower, Rudolf, "The Changing Concept of Proportion", p.210. Zevi also writes: "The hecatomb took place in the early fifteenth century. It was the triumph of perspective. Architects stopped working concretely on architecture and limited themselves to designing it." The Modern Language of Architecture, p.23
} 
in the 1950s does not seem radical. And Le Corbusier would have voted in favour given the chance and would no doubt have back up his view, as he does in The Modulor with an unimpeachable and universally accepted opinion: “..., Einstein had the kindness to say this of the 'Modulor': 'It is a scale of proportions which makes the bad difficult and the good easy.",24

Although most architects (and artists) abandoned their classical fascinations, “... Le Corbusier's answer is quite different. He distinctly believes in the older systems of proportion, newly dressed up by him and his team. The elements of his Modulor are traditional and extremely simple: square, double square, and divisions into extreme and mean ratios ${ }^{, 25}$. This position contrasts, in Wittkower's opinion, with that of the majority of artists (and, of course, architects) whose position can be summed up by these words by Eliel Saarinen (1873-1950): “To lean upon theoretical formulas ... is a sign of weakness that produces weak art. ",26

Wittkower explains how "the break of the arts away from mathematics, however, was no easy task. ... the 'relapses' during the nineteenth century were countless." 27 And according to Ghyka, in 1943 - curiously enough five years the publication of Wittkower's Architectural Principles in the Age of Humanism and the formulation of the Modulor -: "The predominantly scientific character of Renaissance and Baroque Architecture, ... caused in the seventeenth century the anti-geometric or intuitionist reaction whose manifesto was formulated in France by Perrault; and since then there has been an alternation of pendulum swings, ... This conflict between planned composition and intuition or inspiration is still going on, not only in the realm of architecture." ${ }^{28}$ Concerning poetry, Ghyka refers Paul Valéry (1871-1945) whose Eupalinos ou l'architecte ${ }^{29}$, published in 1921, is a clear manifesto for the believe of the close relationship between architecture and music. And Ghyka on Le Corbusier (in 1943): “... Le Corbusier... rediscovered the eternal value of the proportion, of the interplay of proportions within an organic design. He rediscovered also the usefulness of the golden section as a 'regulating theme', ...,30

One should also bear in mind that, although the Golden Section played an unimportant role in Renaissance and post-Renaissance art, in his treatise published in 1854, Adolf Zeising (1810-1876) declared it the central principle of proportion in the macrocosm and microcosm. ${ }^{31}$ In the mid- $19^{\text {th }}$ century, the idea of proportion regained its esoteric and Pythagorean sense. ${ }^{32}$

In his discussions with the organising committee of the De Divina Proportione congress Le Corbusier called attention to the fact that the title meant renouncing past ages, abandoning scientific exegesis and was not a contribution to the studies in question, i.e., "of bringing harmony into modern times"33 arguing that it would "be

\footnotetext{
${ }^{24}$ Le Corbusier, The Modulor, p.58.

${ }^{25}$ Wittkower, Rudolf, "The Changing Concept of Proportion”, p.212.

${ }^{26}$ Wittkower, Rudolf, "The Changing Concept of Proportion", p.211.

${ }^{27}$ Wittkower, Rudolf, "The Changing Concept of Proportion", p.202.

${ }^{28}$ Ghyka, Matila, "Frozen Music", pp.189, 191.

${ }^{29}$ According to Mario Curti, "[t]his text had considerable influence in French intellectual circles during the twenties and thirties of the twentieth century, very likely with respect to proportion and the golden section in particular." "Canons of Proportion and the Laws of Nature", p.5.

${ }^{30}$ Ghyka, Matila, "Frozen Music", p.193.

${ }^{31}$ Wittkower, Rudolf, "The Changing Concept of Proportion”, p.205.

${ }^{32}$ See Curti, Mario, "Canons of Proportion and the Laws of Nature: Observations on a Permanent and Unresolved Conflict".

${ }^{33}$ Le Corbusier, Modulor 2, p.154.
} 
linked most particularly with the works of the Renaissance" ${ }^{\text {34 }}$. He went on to propose changing the name of the Congress to Symmetry for "as it may be adopted today by advance guard of modern thought, pursues a double goal: that of denouncing it's false meaning of equality, maintained by a still vocal academic tradition; and that of putting the concept of symmetry back in its proper place, on the plane of equilibrium: the very essence of proportion" 35 .

Le Corbusier's idea appears to be close to the idea of Symmetry in Antiquity; as it has always been accepted except for the period between mid- $17^{\text {th }}$ and early $20^{\text {th }}$ centuries. In line with Corbusian thought: something akin to commensurability, i.e. the definition of form based on a single measurement unit. Symmetry implies proportion, which is the relationship between elements regardless of the measurement unit. By way of example one could cite Albrecht Dürer's (1471-1528) treatise on proportions, De Symmetria Partium in Rectis Formis Humanorum Corporum (1532). Even for Palladio (1508-1580) ${ }^{36}$, symmetry meant much more than the simple application of a system of commensurable proportions. As he inherited a long tradition, he saw symmetry as a meaningful relationship between numbers in harmony with the cosmic order revealed by Pythagoras and Plato. It appears quite clear that these are Modulor's intentions, too.

One can say that during Renaissance design is a means to achieve harmony - an idea exterior to the object - with academicism it is an end in itself. That is line with Le Corbusier: "The regulating line is a mean to an end; it is not a recipe. Its choice and the modalities of expression given to it are an integral part of architectural creation." 37

And somewhat paradoxically; axial symmetry is, after all, a small part of the history of architecture and HenryRussel Hitchcock (1903-1987) and Philip Johnson's (1906-2005) International Style is not so revolutionary.

\subsection{Architecture and music}

For Le Corbusier ${ }^{38}$ architecture and music were both a question of measure. Sounds can be transmitted via writing only if one heeds two conditions: they are divided into sections and are measured ${ }^{39}$. Or one could say: if they are "geometrized".

Le Corbusier used the term "measure" and it was indeed about measure and not length. The difference between measure and length is fundamental to understanding this point. A metre is nothing more than an abstract number, incapable of describing an interval - a measure in space ${ }^{40}$ [une mesure in the original French edition]. It is, in reality, a dangerous measure in that one runs the risk of it being used in its submultiples, which would not be desirable in architecture. ${ }^{41}$

\footnotetext{
${ }^{34}$ Le Corbusier, Modulor 2, p.154. Here Le Corbusier would seem to reveal a lack of knowledge, given that in the Renaissance the question of commensurability was a fundamental one and that irrational numbers - or measures - were avoided. See Wittkower, Rudolf, "The Changing Concept of Proportion", p.202.

${ }^{35}$ Le Corbusier, Modulor 2, p. 154.

${ }^{36}$ Wittkower, Rudolf, Architectural Principles in the Age of Humanism, p.97.

${ }^{37}$ Le Corbusier, Towards a New Architecture, p.3.

${ }^{38}$ Le Corbusier, The Modulor, p.29.

${ }^{39}$ Le Corbusier, The Modulor, p.16.

${ }^{40}$ Le Corbusier, The Modulor, p.33. Note that this "correction" in the English-language edition clarifies better the notion that was to be expressed.

${ }^{41}$ Le Corbusier, The Modulor, p.33.
} 
Another statement, as included in The Modulor, linking architecture and music is that architecture, like music, is space and time. ${ }^{42}$ For Le Corbusier, architecture does not have a synchronic presence but a diachronic presence, as is the case for music: "Architecture is not a synchronic phenomenon but a successive one, made up of pictures adding themselves one to the other, following each other in time and space, like music." 43

This idea was certainly in line with that of the promenade architecturale. Le Corbusier affirmed that he rejected the principles that governed Renaissance architecture because, in his opinion, the visual perception was neither the main principle nor even one of the generating design principles. The human eye (with its restricted field of vision) is unable to encompass the philosopher's polyhedrons ${ }^{44}$ [polyèdres philosophiques in the original French edition]. This is a fundamental point. For Le Corbusier saw and felt the relationship between architecture and music more from the intuitive and perceptive viewpoint than by means of a composition in which the conceptual aspect played the leading role, the latter being the case with Alberti (1404-1472) or Palladio.

\footnotetext{
${ }^{42}$ Le Corbusier, The Modulor, p.29.

${ }^{43}$ Le Corbusier, The Modulor,p.73.

${ }^{44}$ Le Corbusier, The Modulor, p.72.
} 


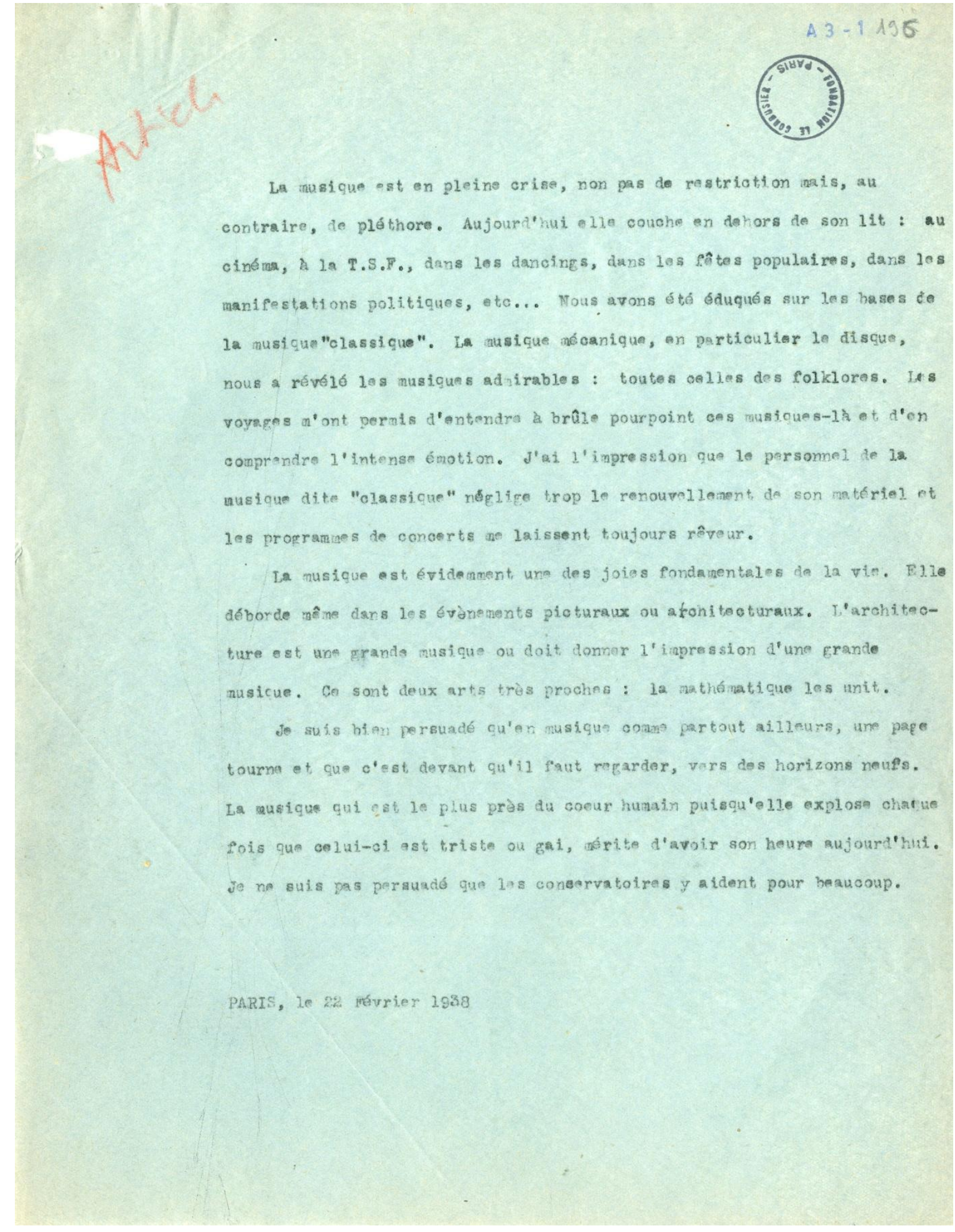

1. Unpublished text on music for La Revue Internationale de Musique. Sent by letter on 22 February 1938 to Charles Leirens of La Maison d'Art. A3(1)195-002@FLC-ADAGP 


\subsection{Working with Xenakis}

A relationship between architecture and music was put into practice in a very fruitful way between 1947 and 1959 - a period in which Le Corbusier and Iannis Xenakis established, through their work relationship, a veritable intellectual partnership in which the musician's and architect's shared interest in, or fascination with, mathematics, and geometry in particular, played a fundamental role. This interest came to manifest itself in a shared course through the development of a theoretical and practical interdisciplinary relationship between architecture and music in which mathematics played an all-important role.

Xenakis was involved in several design projects: the Unité d'Habitation of Marseilles (1947-53), where he was responsible for calculating the concrete structure; the Unité d'Habitation of Rezé-lès-Nantes (1950-55), for which he designed the façades of the crèche located on the terrace, in which one can recognise the neumes of Gregorian musical notation and a "stochastic" 45 distribution of the prefabricated windows calculated on the Modulor ${ }^{46}$; Chandigarh, in particular the Assembly Hall (1951-59) with its enormous hyperboloid; the Convent of Sainte Marie de la Tourette (1953-61); the Maison de la Culture at Firminy (1956-59); and also the Philips Pavilion at the Brussels World Fair of 1958 (1956-58), the design of which he was responsible for and whose experimental attributes were to be of fundamental importance in Xenakis' later trajectory as a composer. ${ }^{47} \mathrm{La}$ Tourette is a key work in this collaboration. Here, Xenakis applied to the fenestration a design based on the score for his composition Metastaseis (1953-54), which itself was influenced by the Modulor.

Although Xenakis had been academically trained in engineering and music and had no prior professional experience as an architect, his collaboration in the master's firm was to take on fundamental importance, precisely due to the possibilities for interdisciplinary work it opened up. And it was this interdisciplinarity that Le Corbusier referenced in relation to Xenakis' collaboration in the design project of Convent of Sainte Marie de la Tourette:

"This design of glazed panels for the convent was made by Xenakis, an engineer who became a musician and is now working as an architect at 35 rue de Sèvres: three favourable vocations united in one man. The way in which music and architecture touch upon one another, so often referred to in connection with the Modulor, is now made manifest professionally in a musical score by Xenakis, 'Metastassis' [sic], in which the resources of the Modulor are used as an aid to musical composition. ",48

The alliance between Le Corbusier and Xenakis provided a relationship of not only mutual disciplinary interpretation but also of mutual disciplinary re-interpretation: architectural design and musical composition methods informed each other well beyond the development of mere theoretical supports; Le Corbusier's design system informed Xenakis' compositional system and, in turn, Xenakis applied principles used in musical composition to the architectural object.

\footnotetext{
${ }^{45}$ A type of music developed and created by Xenakis that used statistics - and probability calculation in particular - in music composition.

${ }^{46}$ Sterken, Sven, "Une invitation à jouer l'espace", p.185.

${ }^{47}$ The attribution of a designer role to Xenakis for the works produced during his time working with Le Corbusier varies depending on the author. Xenakis claims responsibility for a large part of the design of La Tourette, and there is general consensus amongst authors that he designed the Philips Pavilion (with Le Corbusier reluctantly acknowledging him as codesigner). See, for instance, Treib, Marc, Space Calculated in Seconds and Xenakis, Iannis, Musique de l'architecture.

${ }^{48}$ Le Corbusier, Modulor 2, p.326
} 
It was indeed a relationship between architecture, music and mathematics. With the later being the link between the first two. Serving as a guide. Norman Lebrecht ${ }^{49}$ has commented on how the love of the eternal, so often associated with sensibility to mathematics, is evident in Xenakis. Music created through "geometry" was less perishable than works generated by a passing impulse. The structure was fundamental and mathematics should regulate music. This corresponds to the views of Le Corbusier, for whom mathematics would regulate architecture.

\section{The universe, man and architecture}

A link can be established between Corbusian thought and that which corresponds to an idea of a mathematical mathematical-proofed - universe established following traditional principles laid down from Galileo to Newton. Architecture was to be a reflection of that Order:

“..., 'nature is ruled by mathematics, and masterpieces of art are in consonance with nature; they express the laws of nature and themselves proceed from those laws. Consequently, they too are governed by mathematics, and the scholar's impeccable reasoning and unerring formulae may be applied to art. The artist, is a medium of infinite, extraordinary sensitivity; he feels and discerns nature and translates it in his own works. ", 50

An observation that also comes extraordinarily close to the idea advanced by Palladio in the Quatro Libbri: "Since architecture, like all the other arts, imitates nature, nothing (in it) can satisfy that is foreign from what is found in nature." $" 51$

Unlike so many of his generation, his discourse is sometimes so close to a classical discourse; a discourse on the objectivity of beauty. In Antiquity, as illustrated by Luc Ferry ${ }^{52}$, the work of art was conceived as a microcosmos. A microcosmos that expressed an idea that is exterior, that belongs to the outer world - to the macrocosmos. The idea of beauty referred to the world's objectivity: the world created by God and ruled by His harmony. In Antiquity, the artist is not a creator ex nihilo, for what was to be revealed was already there, at a deeper level. The artist is the one who has the good fortune to be able to "translate" a divine message. The classic genius is not he who invents; it is he who discovers. Le Corbusier put himself in that position.

Proportion is the main tool for imitation. Proportion is mimesis in practice.

But the demand for a rule clashes with the architect's inherent taste: the architect must judge with his talent. Le Corbusier seems to reflect the constant difficulty reconciling objectivity and subjectivity that has been patent throughout the history of architecture.

"I will fight against any formula and any set of instruments which take away the least particle of my freedom. I want to keep that freedom so intact that at the very moment when golden figures and the diagrams point to a perfectly orthodox solution I may reply: 'That may be so, but it is not beautiful'. And I conclude, once and for all: 'I do not like this, I do not feel it with my taste, my flair, all the intuition of which I have a good enough share to know when I must decide that here is something I do not want. ",53 But he continues: "Such a decision

\footnotetext{
${ }^{49}$ Lebrecht, Norman, The Companion to $20^{\text {th }}$ Century Music, p.389.

${ }^{50}$ Le Corbusier, The Modulor, pp.29-30. This observation by Le Corbusier is a reproduction of a conversation with Andreas Speiser, then professor at Zurich University.

${ }^{51}$ As cited in James S. Ackerman, Palladio, p.160.

${ }^{52}$ Ferry, Luc, Homo Aestheticus.

${ }^{53}$ Le Corbusier, The Modulor, p.183.
} 
will certainly not imply any attack on mathematics (which is so near to the divine that it will always be ultimately elusive in its infinite withdrawals), ..."54 This reasoning is, in reality, not a modern one. We find the same perplexity in Palladio, for instance. In Quattro Libri (1570), he writes on rules for the proportion of rooms: "There are still other heights for rooms which fall under no rule, and the architect has to use them according to his judgement and need." And "one cannot give a certain and absolute rule about their [measurements of doors and windows] height and with. ${ }^{, 55}$ On the other side of this discussion, Claude Perrault (1613-88), even declaring the subjectivity of the aesthetic judgement, affirmed the architect's need for a profound knowledge of proportion (essential to architecture).

In closing his essay, "The Changing Concept of Proportion", Wittkower writes: "When all is said and done, it must be agreed that the quest for symmetry, balance, and proportional relationships lies deep in human nature. ... the search for systems of proportion in arts will continue as long as art remains an endeavour of man. $" 56$

Apropos the use of metrics and the rejection of the Modulor for future large-scale use, Le Corbusier criticised the French Standardization Organisation, AFNOR, arguing as follows: “... 'the AFNOR proposes to standardize all the objects involved in the construction of buildings. The method they are proposing to employ is somewhat over-simplified: simple arithmetic, getting a simpler cross-section of the methods and costumes used by architects, engineers and manufacturers. This method seems to me to be an arbitrary and a poor one. Take trees: if I look at their trunks and brunches, their leaves and veins, I know that the laws of growth and interchangeability can and should be something subtler and richer." 57

Le Corbusier referenced Anglo-Saxon cultures which still today use the inch and the foot as measurement units, thus maintaining a relationship with the human body: "The Anglo-Saxon society uses the foot-and-inch, which knows nothing of the decimal system... The metre reigns over the other part of the world. I am seriously angry with the metre (forty-millionth part of the meridian of the earth) for having desubstantialized itself as it has done, and for having placed itself so perfectly, so dangerously, so unhappily outside the human scale. ${ }^{58}$

The relationship between the proportions of the human body and architecture also echoed the classical tradition: Le Corbusier highlighted the fact that the measures used in the various civilizations of Antiquity referenced a single standard, whereby the unit used was almost always related to the human body. He goes further and refers to the primitive $\mathrm{e}^{59}$ : “..., I admired the peasants' house, the house of men, the huts, the modest thing on a human scale. And that's where I invented a part of my Modulor, by rediscovering all the human dimensions in humble things. They are based on the cubit, the foot, the inch, etc.,- used from the very beginning of time, because there was no other way to measure. ${ }^{60}$ All measures are "based on man",61.

The Modern showed nostalgia for permanence and, for this reason, found comfort in the classical tradition. It sought rules for representation of the world - interior and exterior - that were considered lost. It also expressed

\footnotetext{
${ }^{54}$ Le Corbusier, The Modulor, p.183.

${ }^{55}$ Wittkower, Rudolf, Architectural Principles in the Age of Humanism, p.129.

${ }^{56}$ Wittkower, Rudolf, "The Changing Concept of Proportion", p.213.

${ }^{57}$ Le Corbusier, The Modulor, p.36. This is a reproduction of a conversation between Le Corbusier and Hanning, one of his colaborators.

${ }^{58}$ Le Corbusier, The Modulor, pp.114-115.

${ }^{59} \mathrm{He}$ advocates the primitive apropos the regulating lines in the chapter "Regulating Lines" in Towards a New Architecture: "Primitive man has brought his chariot to a stop, ..." p.69.

${ }^{60}$ Le Corbusier, "The Final Year: A Transcription and Translation of Le Corbusier's Last Recorded Interview", p.117.

${ }^{61}$ Le Corbusier, "The Final Year: A Transcription and Translation of Le Corbusier's Last Recorded Interview”, p.117.
} 
the idea that the human measurements be present in that relationship. It is also symptomatic that the drawings for the Modulor so clearly mirror the Vitruvian man (as published from Renaissance treatises onwards). [Fig.s 2 and 3]

\section{The Modulor as a synthesis}

Apart from Le Corbusier's personality one should bear in mind that this theme had been present in his mind since his sojourn in Germany in 1910, Matila Ghyka's work on the golden number was fundamental and that, generally, proportions became a central subject of discussion in postwar France. ${ }^{62}$

The title The Modulor: A Harmonious Measure to the Human Scale Universally Applicable to Architecture and Mechanics contains, from the outset, clues to this unequivocal pursuit of order. Measure, harmony, universality, mechanics: four established concepts of order, transversal in history and transversal between themselves.

Unlike the metric system, the "Modulor is a working tool for those who create (those who compose: planners and designers), and not for those who execute (masons, carpenters) ",63. One should note here the traditional one could say, even, classicist - point of view regarding the attribution of different roles and status to those who think and those who execute. This idea had already been strongly rejected in the Bauhaus (for instance) in particular by Walter Gropius (1883-1969) who denounced it in his discourses arguing for the abolishment of the artist-artisan distinction. The connection to classicism - understood as an intellectual attitude reflected in a system of proportions - was also a way of defending the architect's status: "I am not a builder". Just as, during the Renaissance, the architect wasn't also a builder. Leonardo's cosa mentale.

The Modulor presents itself as a manifesto for the cause of a mathematical - arithmetical-geometrical - world. In that world, music affirms its presence as well. The idea of the rule - the ordering instrument - seems to echo music: "The Modulor is a scale. Musicians have a scale; they make music, which may be trite or beautiful." "64 Le Corbusier cites Stamo Papadaki (1906-92), who in his investigation of the Modulor's possible applications, attributed a "subtitle" to it: "“A scale of harmonious measurements of space.",65

And if music seems to be absent it is there, deep down. It is the linking element. It's behind. Like, in Renaissance, for Alberti, as Wittkower clarifies, “... harmonic ratios inherent in nature are revealed in music. The architect who relies on those harmonies is not translating musical ratios into architecture, but is making use of an universal harmony apparent in music." 66

The Modulor also illustrates the proximity between different ages in which there is a desire for a world created by, and continuing to exist as, a natural and universal Order. In this sense, Le Corbusier expresses his wish that the Modulor - as a universal system, as a universal rule - could be an instrument to standardise the diverse measurements of length. He was convinced that the Modulor would find practically unlimited application in geographic and temporal terms. Inspired by Rameau, he sought to create the basis for a new and, if possible, everlasting tradition.

\footnotetext{
${ }^{62}$ See Cohen, Jean-Louis, “Le Corbusier's Modulor and the Debate on Proportion in France”. German culture was absolutly decisive from this point of view.

${ }^{63}$ This is part of a Le Corbusier's answer to a letter by John Dale. Le Corbusier, The Modulor, p.178

${ }^{64}$ Le Corbusier, The Modulor, p.5. In the introduction to the second English-language edition.

${ }^{65}$ Le Corbusier, Modulor 2, p.31.

${ }^{66}$ Wittkower, Rudolf, Architectural Principles in the Age of Humanism, p.109.
} 
Considering Le Corbusier as a follower of the Pythagorean-Platonic tradition, even if he did not declare himself as such, the fact is that he tried - in particular with the Modulor - to reconcile within mathematics the geometric with the arithmetical tradition. While the geometry was usual in the Middle Ages, arithmetic was favoured by Renaissance architects. According to Wittkower, "[i]rrational proportions would have presented a dilemma to Renaissance artists, for the Renaissance attitude to proportion was determined by a new organic approach to nature, which aimed at demonstrating that everything was related to everything by integral number. By contrast, the medieval quest for ultimate truth behind appearances was perfectly answered by geometrical configurations of a decisively fundamental nature",67. And "... the medieval artist tends to impose a pre-established geometrical norm upon his imagery, while the Renaissance artist tends to extract a metrical norm from the natural phenomena that surround him." 68 . And "Modulor" as Summerson ${ }^{69}$ so ably explains is a word derived from module and section d'or. It thus couldn't be closer to ancient times... and tradition.

The Modulor is also a synthesis of commensurability and incommensurability. And whilst, on the one hand, Le Corbusier synthesises those two aspects with the Modulor, on the other the Modulor is also meant to be a synthesis of a different nature: i.e. of the present and tradition. "In the light of history [Modulor] appears as a fascinating attempt to coordinate tradition with our non-Euclidian world."70 The Modulor "... is certainly the first consistent synthesis since the break-down of the older systems, reflecting our own civilisation into bargain. At the same time it testifies to the coherence of our cultural tradition." "71 However "Le Corbusier's dual system of irrational magnitudes is still dependent on the conceptions which Pythagorean-Platonic thought opened up for western mankind." $" 72$

We should risk to say that it is also the synthesis of French ever rationalism with German ever metaphysics...

And it embodies the circle, the square, the circle and the square in relation, double square, the first integers...

But Wittkower considers: “... Le Corbusier's is a composite system, and - in spite of its ultimate derivation from Pythagorean-Platonic thought - its vacillating quality seems to reflect the spirit of our non-Euclidian age.",73 And he argues that: “...by taking man in his environment, instead of universals, as his starting point, Le Corbusier has accepted the shift from absolute to relative standards. His Modulor lacks the metaphysical connotations of the old systems." 74 Is this the case?

The Modulor ensures the mutual relations between the parts and between the parts and the whole. Man and building. The Modulor aims to be a new homo bene figuratus. [Fig.s 2 and 3]

\footnotetext{
${ }^{67}$ Wittkower, Rudolf, "The Changing Concept of Proportion”, p.202

${ }^{68}$ Wittkower, Rudolf, "The Changing Concept of Proportion", p.202

${ }^{69}$ Summerson, John, The Classical Language of Architecture, p.113.

${ }^{70}$ Wittkower, Rudolf, "Systems of Proportion”, p.18.

${ }^{71}$ Wittkower, Rudolf, "Systems of Proportion", p.18.

${ }^{72}$ Wittkower, Rudolf, "Systems of Proportion", p.18.

${ }^{73}$ Wittkower, Rudolf, "The Changing Concept of Proportion”, p.212.

${ }^{74}$ Wittkower, Rudolf, "The Changing Concept of Proportion”, p.212.
} 


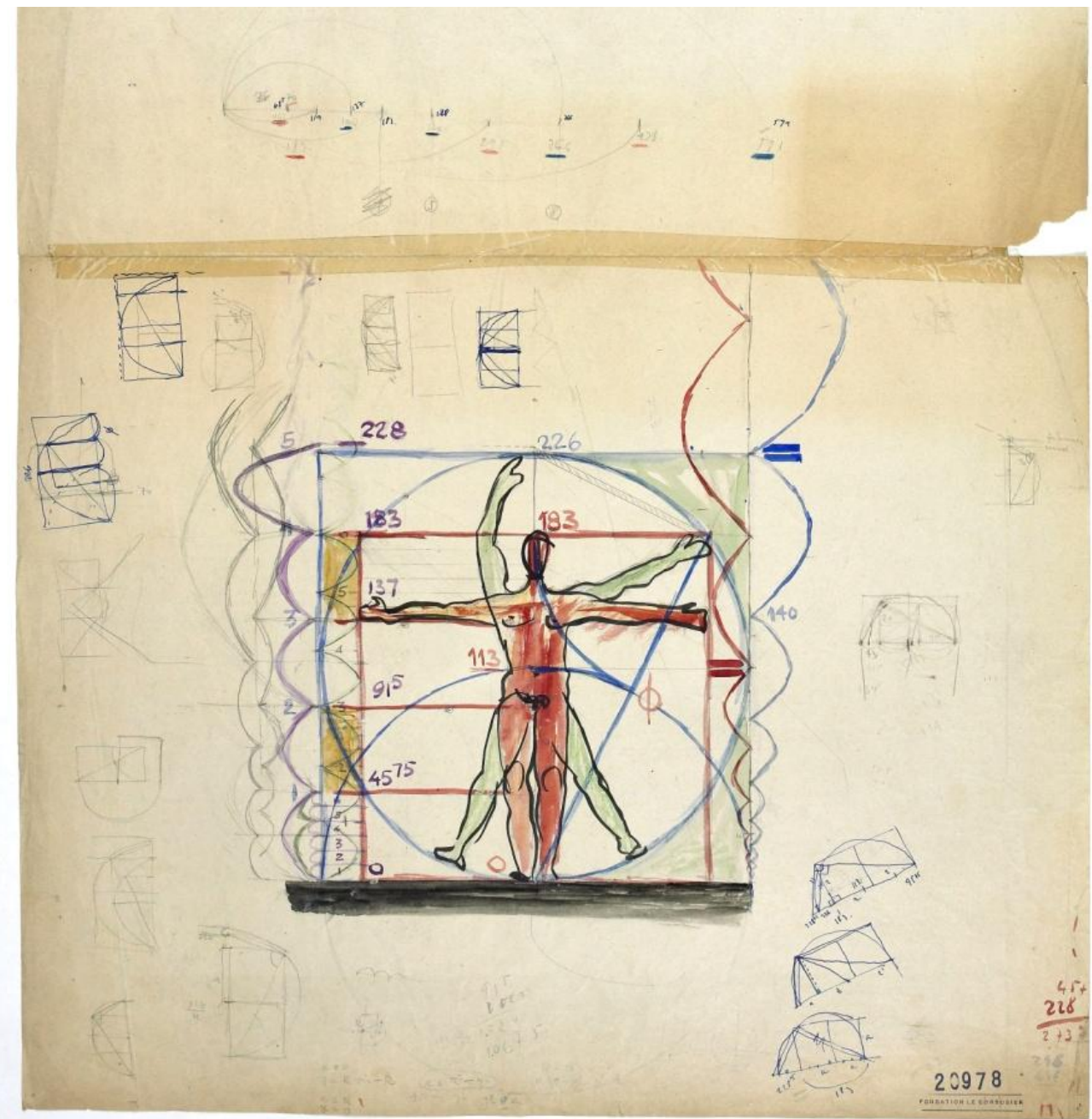

2. Study for the Modulor (undated). Image 32285@FLC-ADAGP 


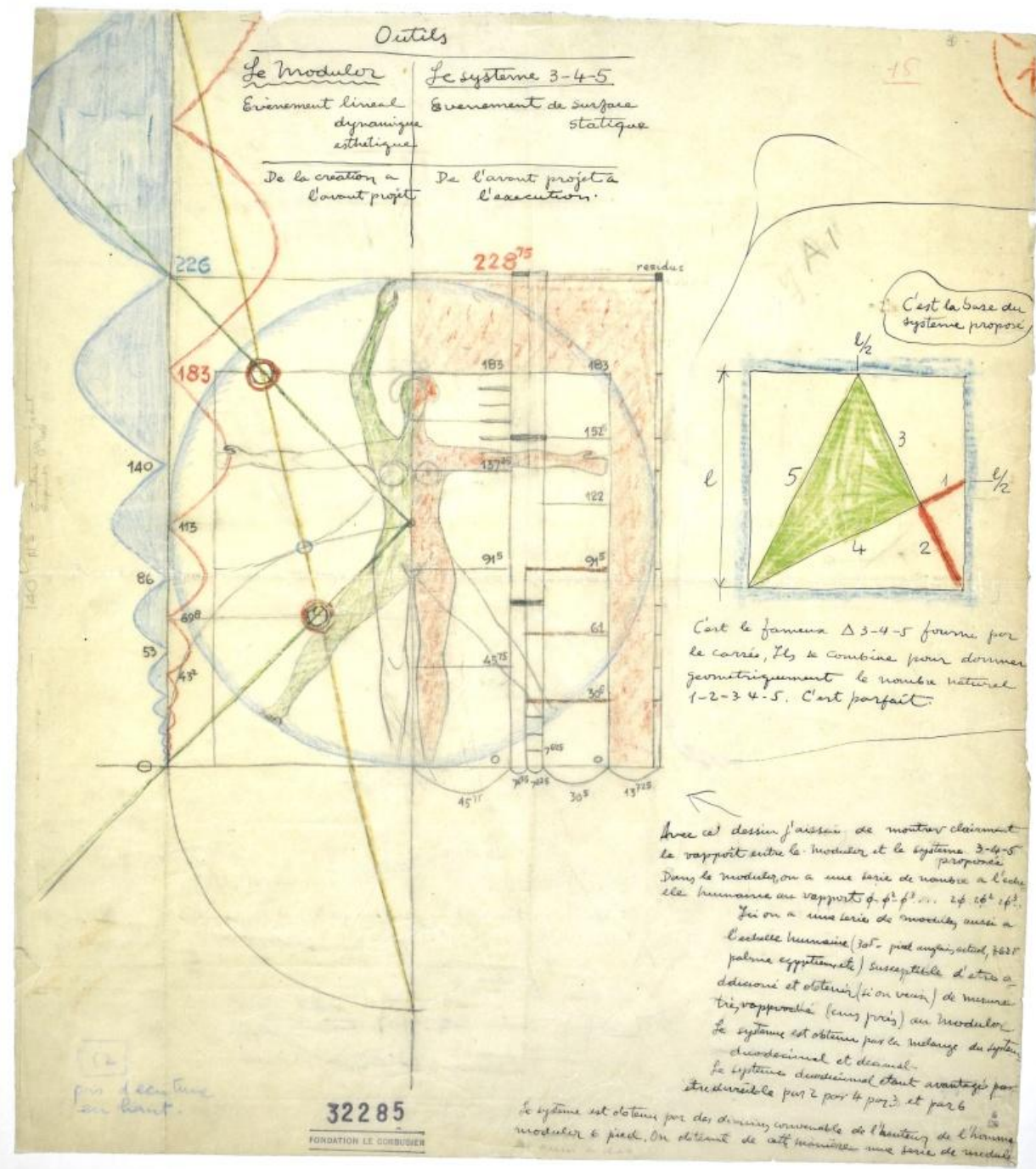

3. Study for the Modulor (undated). Image 20978@ FLC-ADAGP

\section{Longing for classicism}

The question arises: is the architecture-mathematics-music relationship - which embodies Pythagorean-Platonic tradition - the result of nostalgia for the past? Is this nostalgia the result of this love? Or are this love and nostalgia simultaneous manifestations of a way of being, a way of creating? This would seem to be the case. This relationship is so fundamental for it is Le Corbusier's main link to Antiquity and the tradition established then and his wish for a timeless classical thought - a timeless way of thinking and building architecture.

And, even though Le Corbusier did not have the erudite knowledge of music that architects such as Alberti and Palladio had, thanks to his more intuitive and perceptive approach he sought to maintain that relationship. He was convinced that, despite his more intuitive and perception-based approach, the ancestral link between the three disciplines was real. As he wrote in his unpublished article [fig.1]: "[L'architecture et la musique] sont deux arts très proches: la mathématique les unit."

Longing for classicism is the desire to continue an ancient tradition - to a certain extent a "primitive" one while wishing to live and act in the present. Le Corbusier seems to have not wanted to lose this tradition, but the truth is that Romanticism also influenced him. The idiosyncrasies introduced by Romanticism came into conflict 
- a creative and stimulating conflict - with the ideals of the new society founded on an idea of functionalism and rationalism that required the neutrality of the object - the artistic object in general and the architectural object in particular - in relation to personal choices. However, he did not want to give up his position.

If it is true that, as Wittkower states, from the $17^{\text {th }}$ century onwards " [w] hat mathematics gained as an abstract discipline from the seventeenth century on, it lost as a guiding principle in the field of aesthetics" "75 and, simultaneously, "[t] he reciprocal notions 'proportion' and 'beauty' were stripped of their metaphysical and universal character" ", it is this metaphysical aspect that Le Corbusier does not seem to have wanted to abandon. Whereas Edmund Burke (1729-1797) in Enquiry into the origin of our ideas of the Sublime and the Beautiful argued that beauty does not have "anything to do with calculation and geometry"77, Le Corbusier would have countered that it also has to do with them. Le Corbusier did not reject feeling and the subjective, but he did not stop believing in the tradition.

As in the work of Schoenberg, L'Esprit nouveau aspired to becoming a new tradition. Founded on tradition.

And order exists. (And is needed.) As do numbers. And mathematics. They all express the great Order: "Good composition requires the use of a very few elements, but each of those should have a distinct personality, and a strong one at that. It takes only twenty-six letters to write tens of thousands words in fifty languages. [George Sadoul, in a note]. The Universe, at our present state of knowledge, is composed of ninety-two elements. All arithmetic is written with ten figures, and music with seven notes. The year has four seasons, twelve months, and days composed of twenty-four hours. Order is the very key of life." 78

Mathematics - be it geometry or arithmetic - rules human creation. And the universe. Both architecture and music - spatial composition and sound composition - ought to be based on mathematics. Like the universe. And man, the inhabitant of the universe and architecture, through the Modulor, lives and nourishes from that same universe. This is classical thought.

And Le Corbusier's sensibility is very much classical: “... I studied Gothic a lot. I had, for a year - I was in Paris for a whole year - I had the set of keys to Notre-Dame de Paris, given by the ministry to young people who wanted to study it. I wandered around inside, I would go to the top of the towers, into the ambulatories, into every possible corner of Notre-Dame. Notre-Dame is magnificent, it's a very beautiful thing; only my heart is turned toward Greece and not toward the Gothic, which is hard and almost aggressive next to... I'm talking about a Greek feeling and a Gothic feeling. They're two different feelings." ${ }^{, 79}$

An architect, a "musician by heart", a "mathematician by heart" with his heart "turned toward Greece".

Did transcendence exist for Le Corbusier? A transcendent harmony? He refers to "numbers" as "business of the gods". And he states: "Behind the wall, the gods play; they play with numbers, of which the universe is madeup." 80

Le Corbusier: human so human; classical, so classical.

Looking for Harmony.

\footnotetext{
${ }^{75}$ Wittkower, Rudolf, "The Changing Concept of Proportion”, p.202.

${ }^{76}$ Wittkower, Rudolf, "The Changing Concept of Proportion", p.202.

${ }^{77}$ As cited in Wittkower, Rudolf, "The Changing Concept of Proportion". p.202 See also Wittkower, Rudolf, Architectural Principles in the Age of Humanism.

${ }^{78}$ Le Corbusier, The Modulor, p.75.

${ }^{79}$ Le Corbusier, “The Final Year: a Transcription and Translation of Le Corbusier's Last Recorded Interview”, p.120.

${ }^{80}$ Le Corbusier, Modulor 2, p.17.
} 


\section{Acknowledgments}

This paper is funded by National Funds through FCT - Fundação para a Ciência e a Tecnologia under the Project UID/AUR/04026/2013.

Thanks to Fondation Le Corbusier.

Thanks to Delphine Studer (Fondation Le Corbusier).

\section{Bibliographic references}

Ackerman, James S. Palladio. London: Penguin, 1991. [First pub. 1966.]

Cohen, Jean-Louis, “Le Corbusier's Modulor and the Debate on Proportion in France”. Architectural Histories. 2014, Vol.2, Nº1, pp.1-14. DOI: http://dx.doi.org/10.5334/ah.by

Curti, Mario. "Canons of Proportion and the Laws of Nature: Observations on a Permanent and Unresolved conflict”. Architectural Histories. 2014, Vol. 2, No1, pp.1-7. DOI: http://dx.doi.org/10.5334/ah.bn

Curtis, William J.R. Modern Architecture Since 1900. $2^{\text {nd }}$ ed. London: Phaidon, 1995. [First pub. 1982.]

Ferry, Luc. Homo Aestheticus: l'invention du goût à l'âge démocratique. Paris: Éditions Grasset \& Fasquelle, 1990.

Ghyka, Matila. "Frozen Music". Horizon. 1943, N45, pp.187-194.

Gonçalves, Clara Germana, Arquitectura: diálogos com a música: concepção, tradição, criação. Director: Víctor Pérez Escolano. Ph.D Thesis. Universidad de Sevilla: Sevilla, 2008.

Le Corbusier. The Modulor: A Harmonious Measure to the Human Scale Universally Applicable to Architecture and Mechanics. Basel: Birkauser, 2004. [First published as Le Modulor, essai sur une mesure harmonique à l'échelle humaine applicable universellement à l'architecture et à la mécanique. Boulogne: Éditions de l'Architecture d'Aujourd'hui, 1950.]

Le Corbusier. Modulor 2, 1955 (Let the User Speak Next: Continuation of "The Modulor" 1948. Basel: Birkauser, 2004. [First published as Modulor 2, 1955: la parole est aux usagers: suite de "Le Modulor". 1948. Boulogne: Éditions de l'Architecture d'Aujourd'hui, 1955.]

Le Corbusier. Towards a New Architecture. New York: Dover, 1986. [First published as Vers une architecture. Paris: Éditions Crès, 1923.]

Le Corbusier. "The Final Year: a Transcription and Translation of Le Corbusier's Last Recorded Interview". In Zaknic, Ivan (Ed.). The Final Testament of Pére Corbu: a Translation and Interpretation of Mise au point by Ivan Zaknic. New Haven: Yale University Press, 1997, pp.117-120.

Lebrecht, Norman. The Companion to $20^{\text {th }}$ Century Music. New York: Da Capo Press, 1996.

Novak, Marcos. "Breaking the Cage". In Martin, Elizabeth (Ed.). Pamphlet Architecture. "Architecture as a Translation of Music". 1994, Nº16, pp.69-71.

Pevsner, Sir Nikolaus. "Report of a Debate on the Motion 'that Systems of Proportion make good design easier and bad design more difficult"”. R.I.B.A. Journal. Sept.1957, pp.456-463.

Schoenberg, Arnold. Style and Idea: Selected Writings of Arnold Schoenberg. Ed. By Leonard Stein. Berkeley: University of California Press, 1984.

Sterken, Sven. "Une invitation à jouer l'espace: l'itinéraire architectural de Iannis Xenakis”. In Mache, FrançoisBernard (Ed.). Portrait(s) de Iannis Xenakis. Paris: Bibliothèque Nationale de France, 2002, pp.185-193.

Summerson, John. The Classical Language of Architecture. London: Thames and Hudson, 1995. [First pub. 1963] 
Treib, Marc. Space Calculated in Seconds: The Philips Pavilion, Le Corbusier, Edgard Varèse. Princeton, N.J.: Princeton University Press, 1996.

Wittkower, Rudolf. Architectural Principles in the Age of Humanism. London: Academy Editions, 1998. [First published in 1949.]

Wittkower, Rudolf. "The Changing Concept of Proportion". In Wittkower, Rudolf. Idea and Image: Studies in the Italian Renaissance. New York: Thames and Hudson, 1978, pp.198-215. [First published in Architects'Year Book. Vol. V, 1953.]

Wittkower, Rudolf. “Systems of Proportion”. Architects' Year Book. Vol. V, 1953, pp.9-18.

Xenakis, Iannis. Musique. Architecture. Tournai: Casterman, 1971.

Xenakis, Iannis. Musique de l'architecture. Sharon Kanach (Ed.). Marseille: Parenhèses, 2006.

Zevi, Bruno. The Modern Language of Architecture. New York: Da Capo, 1994. [Fisrt published as Il linguaggio moderno dell'architettura: arhitettura e storiografia. Turino: Einaudi, 1973.] 